\title{
Arcobacter halophilus sp. nov., the first obligate halophile in the genus Arcobacter
}

Correspondence

Maqsudul Alam

alam@hawaii.edu

\author{
Stuart P. Donachie, ${ }^{1}$ John P. Bowman, ${ }^{2}$ Stephen L. W. On ${ }^{3}$ \\ and Maqsudul Alam ${ }^{1}$ \\ ${ }^{1}$ Department of Microbiology, University of Hawaii, 2538 The Mall, Honolulu, Hawaii 96822, \\ USA \\ ${ }^{2}$ School of Agricultural Science, University of Tasmania, Private Bag 54, Hobart, Tasmania \\ 7001, Australia \\ ${ }^{3}$ Danish Institute for Food and Veterinary Research, Department of Microbiological Food \\ Safety, Bülowsvej 27, DK-1790 Copenhagen V, Denmark
}

\begin{abstract}
A Gram-negative bacterium, designated $\mathrm{LA}_{3} 1 \mathrm{~B}^{\top}$, was isolated from water collected from a hypersaline lagoon on Laysan Atoll in the north-western Hawaiian Islands. Single cells of LA31B ${ }^{\top}$ were slightly curved but became helical as their length increased. Preliminary characterization based on $16 \mathrm{~S}$ rRNA gene sequence analysis showed that $\mathrm{LA}_{31 \mathrm{~B}^{\top}}$ shared $96.0 \%$ identity with an Arcobacter sp. isolated from a cyanobacterial mat in hypersaline Lake Sinai, and $94 \%$ identity with Arcobacter nitrofigilis, the type species of the genus Arcobacter. A polyphasic taxonomic study was conducted and confirmed the phylogenetic affiliation of strain $L A 31 \mathrm{~B}^{\top}$ to the genus Arcobacter. However, $\mathrm{LA}^{3} 1 \mathrm{~B}^{\mathrm{T}}$ was found to be distinct from all recognized Arcobacter species, by a comprehensive biochemical test analysis, whole-cell fatty acid profiling, DNA G +C content ( 35 mol\% in LA31B ${ }^{\top}$ ) and degree of DNA-DNA reassociation. Most notably, LA31B ${ }^{\top}$ was found to be an obligate halophile, a hitherto undescribed feature among recognized Arcobacter species. These data indicate that $\mathrm{LA}_{3} 1 \mathrm{~B}^{\top}$ should be considered to represent a novel species in the genus Arcobacter, for which the name Arcobacter halophilus sp. nov. is proposed. This is the first obligately halophilic member of the genus. The type strain is $L^{2} 31 \mathrm{~B}^{\top}$ $\left(=\right.$ ATCC BAA $-1022^{\top}=$ CIP $\left.108450^{\top}\right)$.
\end{abstract}

The currently recognized epsilon subdivision of the Proteobacteria represents a taxonomically diverse but phylogenetically distinct group of Gram-negative bacteria that includes the genera Arcobacter, Campylobacter, Helicobacter, Wolinella, Sulfurospirillum, Nautilia, Caminibacter, Sulfurimonas, Sulfurovum and Thiovulum, among others (Vandamme et al., 1991; Schumacher et al., 1992; Alain et al., 2002; Miroshnichenko et al., 2002; Inagaki et al., 2003, 2004; Takai et al., 2004). The ecological niches occupied by these bacteria vary considerably, with some species living in association with various animals (including humans) and other species that are free-living and found in environments such as sea water and anaerobic sludge. Most of the aforementioned genera contain species that are either commensals or pathogens (Campylobacter, Helicobacter, Wolinella) or free-living (Sulfurospirillum, Nautilia, Caminibacter, Thiovulum) but not both. At present, however, the genus

Published online ahead of print on 14 January 2005 as DOI 10.1099/ ijs.0.63581-0.

The GenBank/EMBL/DDBJ accession number for the 16S rRNA gene sequence of $L A 31 B^{\top}$ is $A F 513455$.
Arcobacter is unique among the $\varepsilon$-Proteobacteria as it contains species found in both animal and environmental sources. Three of the four recognized species (Arcobacter butzleri, Arcobacter cryaerophilus and Arcobacter skirrowii) have been recovered from humans and livestock, in which they are often associated with reproductive and/or gastrointestinal diseases (Mansfield \& Forsythe, 2000). The two remaining species are free-living: a nitrogen-fixing bacterium, Arcobacter nitrofigilis, isolated from Spartina alterniflora roots in a salt marsh (McClung et al., 1983), and 'Candidatus Arcobacter sulfidicus', an obligate microaerophile that oxidizes sulfides (Wirsen et al., 2002). Just as more than one species from humans and livestock has been presented, it is likely that the genus will expand as representatives from other habitats are cultivated and described. Indeed, molecular analyses of bacterial strains isolated from seawater and marine sediment samples have detected $16 \mathrm{~S}$ rRNA gene sequences that group in the genus and thus might be considered to be Arcobacter spp. (Llobet-Brossa et al., 1998; Bowman \& McCuaig, 2003; Fera et al., 2004). Identification and classification of Arcobacter and related organisms is challenging because they tend to respond 
poorly, if at all, in conventional biochemical and growth tests (e.g. On, 1996).

During a molecular and cultivation-based survey of prokaryotes from little-explored aquatic habitats in Hawai' $i$, Donachie et al. (2004a) cultivated aerobic heterotrophs from the hypersaline lagoon on Laysan Atoll, including novel species (Donachie et al., 2004b). Laysan Atoll is already recognized for its unique flora and fauna, and hosts over 40 endemic insect and bird species (Ely \& Clapp, 1973; Bakus, 1978). Geographical isolation and high salinity, however, probably keep macrofaunal diversity in the lake low. For example, aquatic vertebrates are absent and the largest invertebrate is an Artemia sp., a genus commonly found in saline lakes (Maciolek, 1982; Savage \& Knott, 1998). Seven million birds that annually use the island deposit guano in and around the lake, an input that probably affects the composition of the lagoon's microbial flora, just as avian populations in other areas affect local lakes and ponds (Lindeboom, 1984). We report here the isolation and characterization of strain $\mathrm{LA} 31 \mathrm{~B}^{\mathrm{T}}$, a Gramnegative bacterium; its nearest reported neighbour is an undescribed strain isolated from Solar Lake, Sinai, Egypt (GenBank/EMBL/DDBJ accession no. L42994; Teske et al., 1996). Phenotypic and genotypic data place the strain firmly in the genus Arcobacter within the e-Proteobacteria, but it can be distinguished from all recognized arcobacters by its obligate halophily and fatty acid composition.

\section{Sample collection and water chemistry}

A water sample was collected directly into a sterile 1 litre Nalgene ${ }^{\circledR}$ bottle from the surface of the hypersaline lagoon at the centre of Laysan Atoll $\left(25^{\circ} 46^{\prime} \mathrm{N}, 171^{\circ} 44^{\prime} \mathrm{W}\right)$ in the north-western Hawaiian Islands in October 2000 (Donachie et al., 2004a). Salinity was determined with an AGE model 2100 Minisal salinometer calibrated against International Association for the Physical Sciences of the Ocean standard (Wormley) sea water.

\section{Enrichment and isolation of bacteria}

A $100 \mu \mathrm{l}$ subsample of water was spread on aspartic acid medium (ASP), based on that of Pochon \& Tardieux (1962), containing (per litre) $1 \mathrm{~g}$ aspartic acid (monosodium salt), 10 g glycerol, $1 \mathrm{~g} \mathrm{~K}_{2} \mathrm{HPO}_{4}, 40 \mathrm{~g} \mathrm{NaCl}, 15 \mathrm{~g}$ agar, $40 \mathrm{~g} \mathrm{NaCl}$ and $1 \mathrm{ml}$ SL8 micronutrient solution (Atlas, 1997). Inoculated plates were incubated aerobically in the dark at $25^{\circ} \mathrm{C}$. A $6 \mathrm{~mm}$ diameter, flat, rough, transparent, eroded, shiny colony was observed after 12 days incubation on ASP. This was designated strain $\mathrm{LA} 31 \mathrm{~B}^{\mathrm{T}}$ and was transferred to marine agar 2216E (Difco) (MA) for purification. Uniform translucent beige colonies of $0 \cdot 5-1 \mathrm{~mm}$ diameter developed within $48 \mathrm{~h}$. Strain purity was checked by microscopy, including Gram-stain and wet mounts, and consistency of colony characteristics. Strain LA31B ${ }^{\mathrm{T}}$ was maintained on MA, or on blood agar (BA), the latter containing Oxoid nutrient broth no. 2, $2 \%$ agar, $5 \%$ whole blood (sheep or horse) and $3.5 \%(\mathrm{w} / \mathrm{v}) \mathrm{NaCl}$. Stock cultures in marine broth 2216E (Difco) (MB) and 30\% (w/v) glycerol were stored frozen at $-80^{\circ} \mathrm{C}$ or lyophilized.

\section{Phenotypic analyses}

Strain LA31B ${ }^{\mathrm{T}}$ was grown microaerobically at room temperature $\left(18-22^{\circ} \mathrm{C}\right)$ on BA for $72 \mathrm{~h}$, and was subsequently examined with an extensive, standardized biochemical identification scheme for arcobacters and related bacteria (On et al., 1996). Additional tests for all temperature and atmospheric tolerances were performed on BA as well as on $\mathrm{BA}$ without supplemental $\mathrm{NaCl}$. Tolerance by $\mathrm{LA} 31 \mathrm{~B}^{\mathrm{T}}$ for $\mathrm{NaCl}$ was tested on trypticase soy agar (TSA) containing

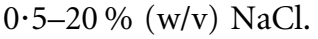

Nitrate reduction was determined in BA supplemented with $0 \cdot 1 \% \mathrm{KNO}_{3}$. Motility was determined in a hanging-drop preparation under a $100 \times$ oil-immersion objective using cells grown for $24 \mathrm{~h}$ in MB. Fatty acids in whole cells on $\mathrm{BA}$ and $\mathrm{MB}$ were identified by using the MIDI Sherlock Microbial Identification System (Sasser, 1997). Cells grown for $72 \mathrm{~h}$ in MB were prepared for scanning electron microscopy according to the method of Donachie et al. (2002). In addition, cells from a 10 day culture on BA were suspended in $10 \mu \mathrm{l}$ of $1 \%$ glutaraldehyde with $0.05 \%$ sodium cacodylate $(\mathrm{pH} 7 \cdot 4)$ on a Formvar-coated copper grid. After $30 \mathrm{~s}$ the cells were washed twice with sterile distilled water and negatively stained with $1 \%$ uranyl acetate. Negatively stained cells were viewed in a Leo 912 energy-filtered transmission electron microscope at $100 \mathrm{kV}$, and digital images were captured using a Proscan HighSpeed Slow-Scan System Controller.

\section{DNA isolation and phylogenetic analyses}

Genomic DNA was extracted from cultures of strain LA31B ${ }^{\mathrm{T}}$ grown for $72 \mathrm{~h}\left(\mathrm{MB}, 30^{\circ} \mathrm{C}\right.$, shaking at 100 r.p.m.) using the G NOME DNA extraction kit (Qbiogene). A $\sim 1.5 \mathrm{~kb}$ fragment of the 16S rRNA gene was amplified from genomic DNA in a PCR with $P f u$ DNA polymerase and the primers 27F and 1492R (Lane, 1991). Thermal cycling conditions were as follows: initial denaturation at $94^{\circ} \mathrm{C}$ for $3 \mathrm{~min}$ followed by 30 cycles of $94^{\circ} \mathrm{C}$ for $45 \mathrm{~s}, 55^{\circ} \mathrm{C}$ for $1 \mathrm{~min}$ and $72{ }^{\circ} \mathrm{C}$ for $90 \mathrm{~s}$. The final extension step was carried out at $72{ }^{\circ} \mathrm{C}$ for $7 \mathrm{~min}$, followed by cooling to $4{ }^{\circ} \mathrm{C}$. The PCR product was purified by using a Qiagen PCR purification kit. The purified PCR product was sequenced in both directions in a Beckmann CEQ2000 DNA analyser using the Beckmann sequencing kit and the primers 27F, 519R, 533F and 1492R (Lane, 1991). Nucleotide sequences that had been assembled and edited in SEQMAN (DNASTAR) were aligned in CLUSTAL_X (Thompson et al., 1997) with 16S rRNA gene sequences of $\varepsilon$-Proteobacteria type strains and affiliated strains retrieved from GenBank. The relationship of $L A 31 B^{T}$ with these bacteria was visualized on the basis of their $16 \mathrm{~S}$ rRNA nucleotide sequences in a phylogenetic tree constructed from a CLUSTAL_X alignment using the neighbour-joining method (Saitou \& Nei, 1987), corrected for multiple substitutions, and re-rooted in NJPLOT 
(Perrière \& Gouy, 1996). The tree was rendered in TreeView (Page, 1996) and into Adobe ${ }^{\circledR}$ Illustrator ${ }^{\circledR}$ for publication.

\section{DNA-DNA reassociation}

Genomic DNA was extracted from strain LA31B ${ }^{\mathrm{T}}$ grown in MB using phenol and chloroform (Marmur, 1961). The $\mathrm{G}+\mathrm{C}$ content was determined following the method of Sly et al. (1986). Genomic DNA was hybridized with that from the type strains of A. nitrofigilis NCTC $12251^{\mathrm{T}}$, A. butzleri NCTC $12481^{\mathrm{T}}$, A. cryaerophilus NCTC $11885^{\mathrm{T}}$ and $A$. skirrowii NCTC $12713^{\mathrm{T}}$ according to the methods of $\mathrm{Huß}$ et al. (1983) and Bowman et al. (1998). Hybridizations were carried out in $2 \times$ SSC buffer, with renaturation at $64{ }^{\circ} \mathrm{C}$, but owing to the higher $\mathrm{G}+\mathrm{C}$ content of the DNA in $\mathrm{LA} 31 \mathrm{~B}^{\mathrm{T}}$, the procedure was modified. After shearing by sonication, the DNA was filtered through a sterile $0 \cdot 2 \mu \mathrm{m}$ filter and transferred to cuvettes for denaturation within the spectrophotometer (GBC916 spectrophotometer; GBC Instruments) at $95^{\circ} \mathrm{C}$ for $10 \mathrm{~min}$. With the cuvette temperature at more than $90^{\circ} \mathrm{C}, 20 \times$ SSC (pre-heated to $\sim 90^{\circ} \mathrm{C}$ ) was added to increase the final salt concentration to $2 \times$ SSC. The contents were rapidly mixed by pipette. The cuvette temperature was then set to the optimal renaturation temperature and allowed to equilibrate for $5 \mathrm{~min}$ before measurement of renaturation commenced.

\section{Habitat, cell morphology and phenotypic characteristics}

Salinity at the sample collection point was 76 p.p.t. Colonies of $\mathrm{LA} 31 \mathrm{~B}^{\mathrm{T}}$ that arose on MA after transfer from ASP were dull-white to cream, low convex, circular, entire, smooth, dull, opaque, often punctiform and rarely exceeded $1 \mathrm{~mm}$ in diameter. Colonies developed most rapidly on BA containing $3.5 \% \mathrm{NaCl}$. Cells were curved rods, becoming slightly helical (Fig. 1a). They were also motile with a single polar flagellum (Fig. 1b, c). The comprehensive phenotyping scheme used to characterize strain $\mathrm{LA} 31 \mathrm{~B}^{\mathrm{T}}$ was developed principally to identify species of human and veterinary relevance, with some free-living species included for completeness (On et al., 1996). Although the basal media used for the numerous tolerance tests were identified as those giving the most reproducible results for these organisms (On \& Holmes, 1991), the same media do not contain sufficient $\mathrm{NaCl}$ to support growth of $\mathrm{LA} 31 \mathrm{~B}^{\mathrm{T}}$. The small number of positive results for the tolerance tests included in the scheme highlights the halophilic nature of $\mathrm{LA} 31 \mathrm{~B}^{\mathrm{T}}$, and contributes to the ease by which the strain can be discriminated from other Arcobacter species (Table 1). Nevertheless, LA31B ${ }^{\mathrm{T}}$ also shares typical features of recognized Arcobacter species, namely hydrolysis of indoxyl acetate, plus microaerophilic and aerobic growth at room temperature $\left(\sim 18-25^{\circ} \mathrm{C}\right)$. Moreover, $\mathrm{LA} 31 \mathrm{~B}^{\mathrm{T}}$ grows anaerobically at room temperature and at $37^{\circ} \mathrm{C}$ on BA containing $3.5 \%$ (w/v) $\mathrm{NaCl}$. There is no growth at $42^{\circ} \mathrm{C}$.

LA $31 B^{T}$ grows well on media containing $2-4 \%(w / v) ~ N a C l$ or $0.1 \%$ potassium nitrate (used for assessing nitrate
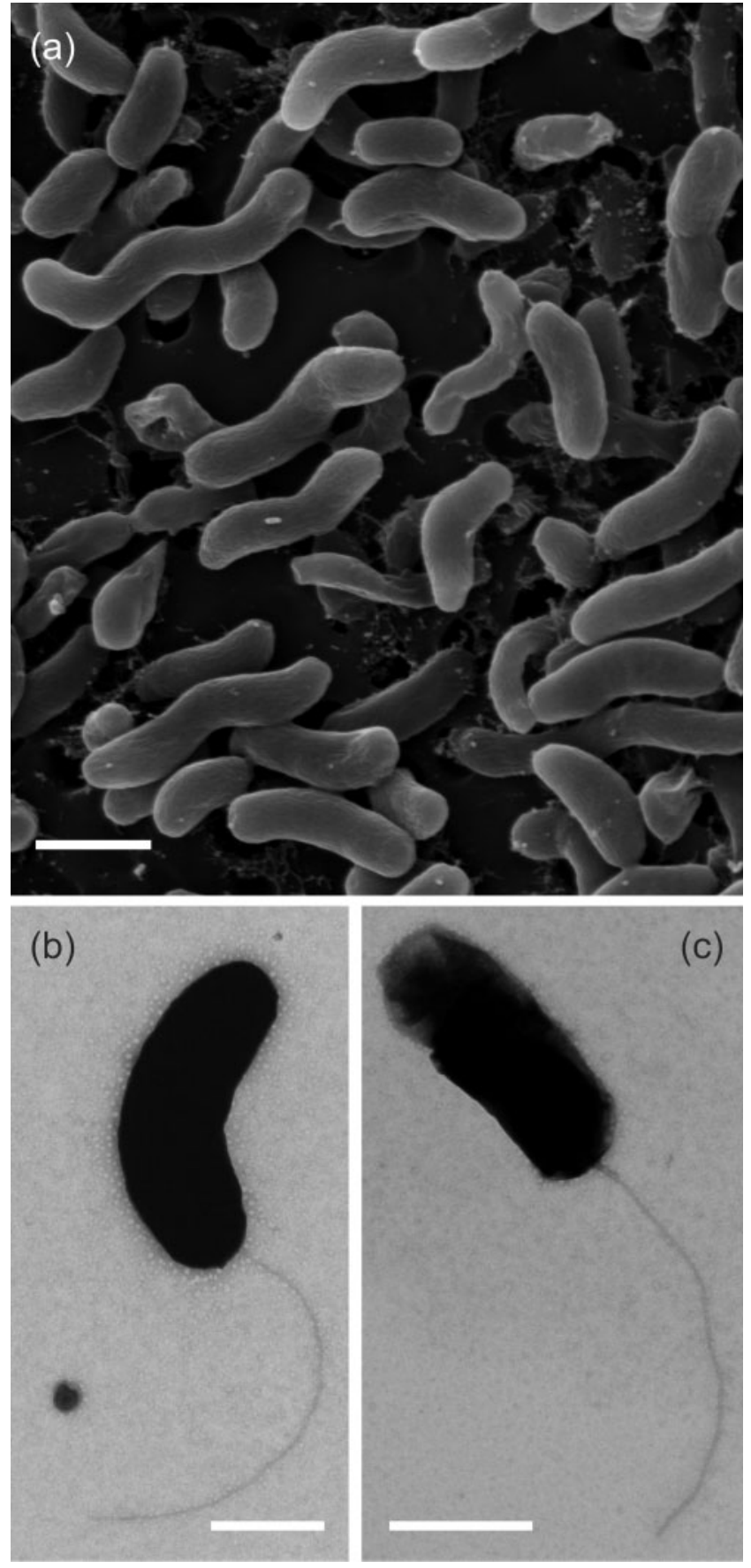

Fig. 1. (a) Scanning electron micrograph of cells of Arcobacter halophilus sp. nov. Bar, $1 \mu \mathrm{m}$. (b, c) Negatively stained cells of A. halophilus showing single polar flagellum. Bars, $0.5 \mu \mathrm{m}$. See text for preparation procedures.

reduction). We suspect the potassium fulfils the physiological requirements otherwise provided by sodium, albeit at a much lower concentration. The strain grows on TSA containing $0 \cdot 5-13 \cdot 5 \%(\mathrm{w} / \mathrm{v}) \mathrm{NaCl}$. In the absence of supplemental $\mathrm{NaCl}$, however, nutrient, charcoal, starch, MacConkey, lecithin, tyrosine, casein and BA media do not 
Table 1. Characteristics that differentiate Arcobacter halophilus sp. nov. $\mathrm{LA} 1 \mathrm{~B}^{\mathrm{T}}$ from $A$. butzleri, $A$. cryaerophilus, $A$. nitrofigilis and $A$. skirrowii

1, A. halophilus ( $n=1$ strain); 2, A. nitrofigilis $(n=2) ; 3$, A. cryaerophilus $(n=19) ; 4$, A. butzleri $(n=12) ; 5$, A. skirrowii $(n=9)$. Percentage of strains testing positive is shown. Data for Arcobacter reference species were taken from On et al. (1996) and Atabay et al. (1998). All strains were oxidase-positive, reduced nitrate and grew in air at $25^{\circ} \mathrm{C}$.

\begin{tabular}{|lrrrrr|}
\hline Characteristic & $\mathbf{1}$ & $\mathbf{2}$ & $\mathbf{3}$ & $\mathbf{4}$ & $\mathbf{5}$ \\
\hline Catalase activity & 0 & 100 & 100 & 33 & 100 \\
Urease activity & 0 & 100 & 0 & 0 & 0 \\
Growth in: & & & & & \\
$\quad$ Air at $37^{\circ} \mathrm{C}$ & 100 & 50 & 50 & 100 & 100 \\
$2 \%(\mathrm{w} / \mathrm{v}) \mathrm{NaCl}$ & 100 & 100 & 84 & 92 & 100 \\
$4 \%(\mathrm{w} / \mathrm{v}) \mathrm{NaCl}$ & 100 & 100 & 0 & 0 & 100 \\
Percentage of strains resistant to: & & & & & \\
$\quad$ Cephalothin $\left(32 \mathrm{mg} \mathrm{l}^{-1}\right)$ & 0 & 0 & 100 & 100 & 100 \\
$\quad$ Carbenicillin & 0 & 0 & 100 & 100 & 100 \\
$\quad$ Methyl orange & 0 & 0 & 100 & 100 & 100 \\
& & & & & \\
\hline
\end{tabular}

support growth, despite incubation periods of up to 4 weeks. The strain grew vigorously on BA when $3.5 \%$ (w/v) $\mathrm{NaCl}$ was added. Obligate halophily is thus the main

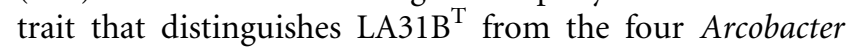
species with validly published names (Table 1). A detailed description of the phenotype of $L A 31 \mathrm{~B}^{\mathrm{T}}$ is given below.
The major fatty acids in whole cells of $\mathrm{LA} 3 \mathrm{~B}^{\mathrm{T}}$ are hexadecanoic $\left(\mathrm{C}_{16: 0}\right)$, cis-9-hexadecenoic acid $\left(\mathrm{C}_{16: 1} \omega 7 c\right)$ and cis-9-octadecanoic acid $\left(\mathrm{C}_{18: 1} \omega 7 c\right)$ (Table 2). Finster et al. (1997) described the potential taxonomic value of the fatty acid composition of Campylobacter-HelicobacterArcobacter strains. In this respect, a relationship between strain $\mathrm{LA}_{3} 1 \mathrm{~B}^{\mathrm{T}}$ and $A$. nitrofigilis is supported by the absence from only these two within the genus of $\mathrm{C}_{14: 1}$ cis 7 and $\mathrm{C}_{16: 1}$ trans 9 , whereas only they contain $\mathrm{C}_{12: 0} 3-\mathrm{OH}$. In terms of differentiating $\mathrm{LA} 31 \mathrm{~B}^{\mathrm{T}}$, however, only this strain within the genus lacks $\mathrm{C}_{14: 0} 3-\mathrm{OH}$.

\section{Genomic analyses}

The nucleotide sequence of the $16 \mathrm{~S}$ rRNA gene in $L A 31 \mathrm{~B}^{\mathrm{T}}$ shares $94 \%$ identity over 1402 bases with that of $A$. nitrofigilis NCTC $12251^{\mathrm{T}}$, its nearest neighbour on this basis, and only 91-93\% with the other recognized arcobacters. The nucleotide sequence of the 16S rRNA gene of strain $\mathrm{LA}_{31 \mathrm{~B}^{\mathrm{T}}}$ falls firmly within the genus Arcobacter (Fig. 2). The $\mathrm{G}+\mathrm{C}$ content of strain $\mathrm{LA} 31 \mathrm{~B}^{\mathrm{T}}$ (35 mol\%) also differentiates it from recognized arcobacters, namely $A$. butzleri NCTC $12481^{\mathrm{T}}$ and A. cryaerophilus NCTC $11885^{\mathrm{T}}$ (28 $\mathrm{mol} \%$ ), and A. nitrofigilis NCTC $12251^{\mathrm{T}}$ and $A$. skirrowii NCTC $12713^{\mathrm{T}}(29 \mathrm{~mol} \%)$. The same type strains of $A$. nitrofigilis and A. skirrowii showed only $4 \%$ DNA-DNA reassociation with $\mathrm{LA} 31 \mathrm{BT}$, while $A$. butzleri and $A$. cryaerophilus showed 10 and $12 \%$ DNA-DNA reassociation, respectively (these values are means of three to four replicate analyses). These data suggest that $\mathrm{LA}_{3} 1 \mathrm{~B}^{\mathrm{T}}$ cannot

Table 2. Fatty acid composition of Arcobacter halophilus sp. nov. and recognized members of the genus Arcobacter

Strains: 1, A. halophilus on MA, $30^{\circ} \mathrm{C} ; 2$, A. halophilus on $\mathrm{BA}, 37^{\circ} \mathrm{C} ; 3$, A. nitrofigilis; 4, A. butzleri; 5, A. skirrowii; 6, A. cryaerophilus subgroup 1; 7, A. cryaerophilus subgroup 2. -, Not determined or less than 1\%. Data for 3-7 are from Vandamme et al. (1992).

\begin{tabular}{|c|c|c|c|c|c|c|c|}
\hline Fatty acid & 1 & 2 & 3 & 4 & 5 & 6 & 7 \\
\hline $\mathrm{C}_{14: 0}$ & $5 \cdot 40$ & $5 \cdot 04$ & $4 \cdot 8$ & $4 \cdot 8$ & $2 \cdot 4$ & $1 \cdot 8$ & $1 \cdot 7$ \\
\hline $\mathrm{C}_{15: 0}$ anteiso & - & $0 \cdot 31$ & - & - & - & - & - \\
\hline $\mathrm{C}_{16: 0}$ & $25 \cdot 77$ & $19 \cdot 31$ & $32 \cdot 0$ & $19 \cdot 6$ & $22 \cdot 2$ & $18 \cdot 7$ & $17 \cdot 8$ \\
\hline $\mathrm{C}_{14: 1}$ cis 7 & - & - & - & $4 \cdot 9$ & $1 \cdot 4$ & $9 \cdot 2$ & $9 \cdot 2$ \\
\hline $\mathrm{C}_{16: 1}$ iso $\mathrm{I}$, or $\mathrm{C}_{14: 0} 3 \mathrm{OH}$ or $12: 0$ alde & $2 \cdot 39$ & $2 \cdot 07$ & - & - & - & - & - \\
\hline $\mathrm{C}_{16: 1} \omega 5 c$ & - & $0 \cdot 42$ & - & - & - & - & - \\
\hline $\mathrm{C}_{16: 1} \omega 7 c$ & $25 \cdot 90$ & $37 \cdot 92$ & $30 \cdot 9$ & $19 \cdot 2$ & $22 \cdot 8$ & $45 \cdot 2$ & $19 \cdot 0$ \\
\hline $\mathrm{C}_{16: 1}$ trans 9 & - & - & - & $13 \cdot 8$ & $7 \cdot 8$ & - & $18 \cdot 8$ \\
\hline $\mathrm{C}_{14: 0} 3 \mathrm{OH}$ & - & - & $5 \cdot 3$ & $17 \cdot 4$ & $9 \cdot 2$ & $9 \cdot 4$ & $14 \cdot 3$ \\
\hline $\mathrm{C}_{19}$ cyclo $\omega 10 c$ & - & $0 \cdot 52$ & - & - & - & - & - \\
\hline Named (\%) & 100 & $98 \cdot 94$ & $98 \cdot 5$ & $98 \cdot 1$ & $94 \cdot 6$ & $98 \cdot 6$ & $99 \cdot 3$ \\
\hline
\end{tabular}




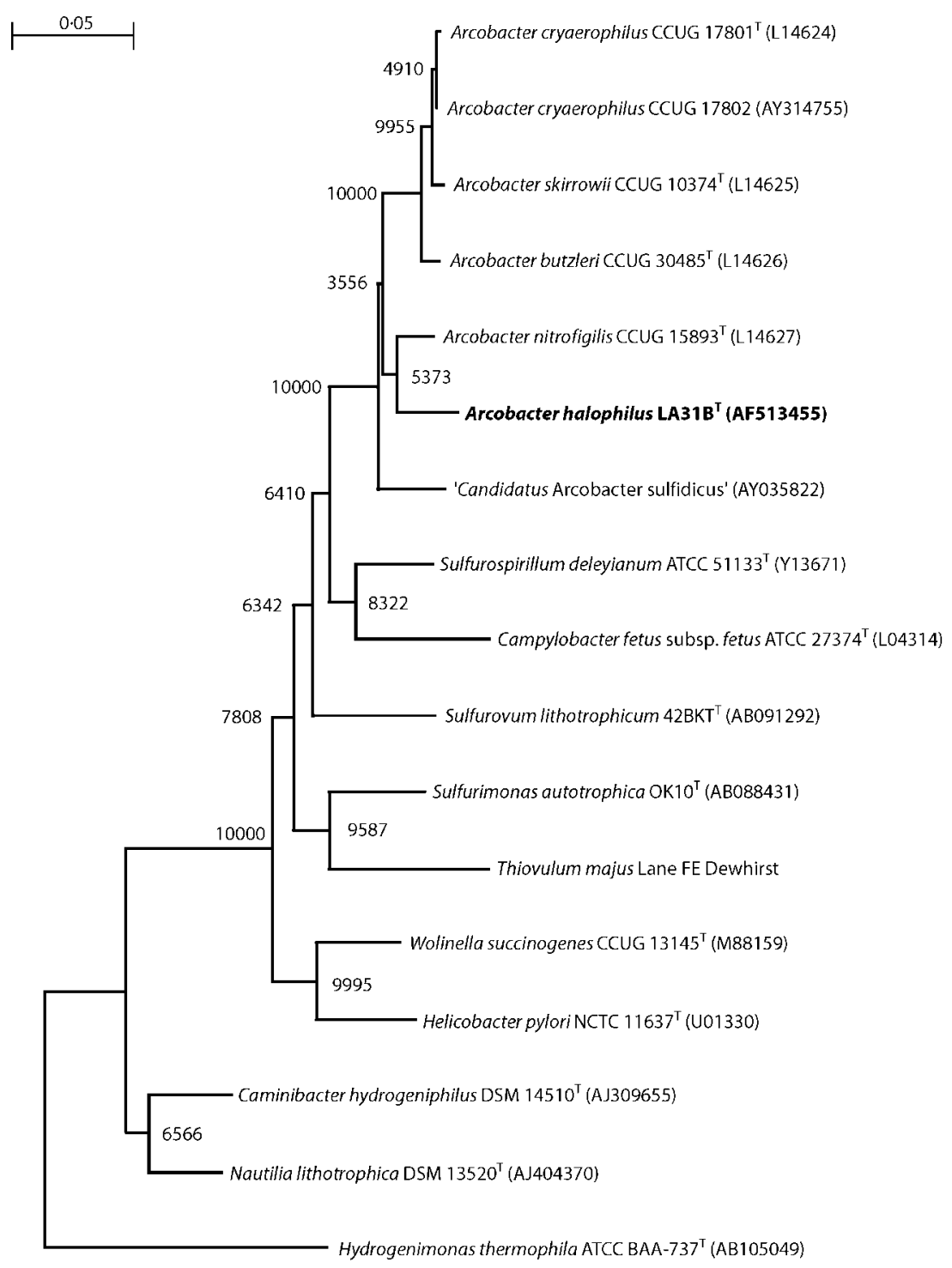

Fig. 2. Phylogenetic tree showing the relationship of Arcobacter halophilus sp. nov. $\mathrm{LA31B}^{\mathrm{T}}$ with representatives of the $\varepsilon^{-}$ Proteobacteria, on the basis of 1133 nucleotides from the 16S rRNA gene. See text for a description of the alignment and presentation procedures. The $\varepsilon$-proteobacterium Hydrogenimonas thermophila ATCC BAA$737^{\top}$ was used as the outgroup. Numbers at nodes are bootstrap values based on 10000 replicates. Bar, 0.05 nucleotide substitutions per site. be considered to represent any of the recognized Arcobacter species (Wayne et al., 1987).

In light of the differences described here between $L A 31 B^{T}$ and recognized Arcobacter species, we propose that $\mathrm{LA}_{31 \mathrm{~B}^{\mathrm{T}}}$ is the type strain of a novel species within the genus, for which the name Arcobacter halophilus sp. nov. is proposed. We believe this is the first documented report of an obligately halophilic Arcobacter species.

\section{Description of Arcobacter halophilus sp. nov.}

Arcobacter halophilus (ha.lo' phi.lus. Gr. n. hals halos salt; Gr. adj. philos loving; N.L. masc. adj. halophilus salt-loving).

Cells are slightly curved rods, becoming helical as cells lengthen, $0 \cdot 4-0 \cdot 5 \mu \mathrm{m}$ wide and $1 \cdot 5-2 \cdot 5 \mu \mathrm{m}$ long. Cells stain Gram-negative. After $72 \mathrm{~h}$ incubation at $18-22^{\circ} \mathrm{C}$ under microaerobic conditions on $5 \%$ blood agar containing $3.5 \% \mathrm{NaCl}$, colonies are smooth, off-white, circular with entire margins, convex, non-swarming with a sticky consistency and $\sim 1-2 \mathrm{~mm}$ in diameter. Cells are motile by a single polar flagellum. Does not grow, or grows only poorly, on media that contain less than $2 \% \mathrm{NaCl}$ or less than $0.1 \% \mathrm{KNO}_{3}$. Oxidase is produced. Indoxyl acetate is hydrolysed. Nitrate is reduced. Does not produce catalase, urease, alkaline phosphatase or DNase. Hippurate is not hydrolysed. Haemolysis is not observed. Hydrogen sulfide is not produced in triple-sugar iron agar. When tested on $5 \%$ blood agar containing $3 \cdot 5 \% \mathrm{NaCl}$, growth is observed under aerobic and microaerobic conditions at room temperature and at $37^{\circ} \mathrm{C}$, and under anaerobic conditions at $37^{\circ} \mathrm{C}$. Growth is not observed on $5 \%$ blood agar containing $3 \cdot 5 \% \mathrm{NaCl}$ under microaerobic conditions at $42{ }^{\circ} \mathrm{C}$. Grows microaerobically on 5\% BA containing 2-4\% $(\mathrm{w} / \mathrm{v}) \mathrm{NaCl}$. Growth is not observed under microaerobic conditions on nutrient, charcoal, minimal, MacConkey, potato starch, lecithin, tyrosine or casein media. Growth is not observed under microaerobic conditions on media containing $0.04 \%$ triphenyl-tetrazolium chloride, $1 \%$ glycine, $0 \cdot 1 \%$ potassium permanganate, $0 \cdot 001 \%$ sodium 
arsenite, $0 \cdot 02-0 \cdot 05 \%$ safranin, $32 \mathrm{mg}$ nalidixic acid $\mathrm{l}^{-1}$, $32 \mathrm{mg}$ cephalothin $\mathrm{l}^{-1}, 32 \mathrm{mg}$ carbenicillin $\mathrm{l}^{-1}, 64 \mathrm{mg}$ cefoperazone $1^{-1}, 0 \cdot 032 \%$ methyl orange, $0 \cdot 1 \%$ sodium deoxycholate, $0.005 \%$ basic fuchsin, $0.0005 \%$ crystal violet, $0 \cdot 01 \%$ janus green, $0 \cdot 1 \%$ sodium fluoride or $0 \cdot 2 \%$ pyronin. Major fatty acids in whole cells grown for $72 \mathrm{~h}$ on BA or MA are $\mathrm{C}_{16: 1} \omega 7 c, \mathrm{C}_{18: 1} \omega 7 c$ and $\mathrm{C}_{16: 0} ; \mathrm{C}_{14: 0} 3-\mathrm{OH}$ is absent.

The type strain is $\mathrm{LA} 31 \mathrm{~B}^{\mathrm{T}}\left(=\mathrm{ATCC}\right.$ BAA $-1022^{\mathrm{T}}=\mathrm{CIP}$
$\left.108450^{\mathrm{T}}\right)$.

\section{Acknowledgements}

This work was supported under NSF Microbial Observatories Program grant \#MCB0084326 to M. A. We thank the US Fish \& Wildlife Service, and the Department of Land and Natural Resources for assistance. We are indebted to Dr Jim Maragos, Chief Scientist of the NOW-RAMP-II cruise. Thanks also to the captain and crew of the MV Rapture, the NOW-RAMP II participants, Renee Harada for assistance in the field, Nina Helene Langhoff for technical assistance in phenotyping and Tracey Freitas for generating the phylogenetic tree. We gratefully acknowledge Dr Jean Euzéby for assistance with Latin grammar.

\section{References}

Alain, K., Querellou, J., Lesongeur, F., Pignet, P., Crassous, P., Raguenes, G., Cueff, V. \& Cambon-Bonavita, M. A. (2002). Caminibacter hydrogeniphilus gen. nov., sp. nov., a novel thermophilic, hydrogen-oxidizing bacterium isolated from an East Pacific Rise hydrothermal vent. Int J Syst Evol Microbiol 52, 1317-1323.

Atabay, H. I., Corry, J. E. L. \& On, S. L. W. (1998). Diversity and prevalence of Arcobacter spp. in broiler chickens. J Appl Microbiol 84, 1007-1016.

Atlas, R. M. (1997). Handbook of Microbiological Media, 2nd edn, p. 7. Boca Raton, FL: CRC Press.

Bakus, G. J. (1978). Wildlife refuges and endangered species of the Hawaiian Islands and Trust Territory of the Pacific islands. In Literature Review and Synthesis of Information on Pacific Island Ecosystems, pp. 1-105. Edited by J. E. Byrne. Final Report, Documentation Associates Information Services Incorporated, Los Angeles, CA. Report for the Office of Biological Services, Fish and Wildlife Service, US Department of the Interior. Contract no. 14-160009-77-075.

Bowman, J. P. \& McCuaig, R. D. (2003). Biodiversity, community structural shifts, and biogeography of prokaryotes within Antarctic continental shelf sediment. Appl Environ Microbiol 69, 2463-2483.

Bowman, J. P., McCammon, S. A., Lewis, T., Skerratt, J. H., Brown, J. L., Nichols, D. S. \& McMeekin, T. A. (1998). Psychroflexus torquis gen. nov., sp. nov., a psychrophilic species from Antarctic sea ice, and reclassification of Flavobacterium gondwanense (Dobson et al. 1993) as Psychroflexus gondwanense gen. nov., comb. nov. Microbiology 144, 1601-1609.

Donachie, S. P., Christenson, B. W., Kunkel, D. D., Malahoff, A. \& Alam, M. (2002). Microbial community in acidic hydrothermal waters of volcanically active White Island, New Zealand. Extremophiles 6, 419-425.
Donachie, S. P., Hou, S., Lee, K.-S. \& 11 other authors (2004a). The Hawaiian Archipelago: a microbial diversity hotspot. Microb Ecol 48, 509-520.

Donachie, S. P., Bowman, J. P. \& Alam, M. (2004b). Psychroflexus tropicus sp. nov., an obligately halophilic halophilic CytophagaFlavobacterium-Bacteroides group bacterium isolated from an Hawaiian hypersaline lake. Int J Syst Evol Microbiol 54, 935-940.

Ely, C. A. \& Clapp, R. B. (1973). The natural history of Laysan Island, Northwestern Hawaiian Islands. Atoll Res Bull 171, 1-361.

Fera, M. T., Maugeri, T. L., Gugliandolo, C., Beninati, C., Giannone, M., La Camera, E. \& Carbone, M. (2004). Detection of Arcobacter spp. in the coastal environment of the Mediterranean Sea. Appl Environ Microbiol 70, 1271-1276.

Finster, K., Liesack, W. \& Tindall, B. J. (1997). Sulfurospirillum arcachonense sp. nov., a new microaerophilic sulfur-reducing bacterium. Int J Syst Bacteriol 47, 1212-1217.

Huß, V. A. R., Festl, H. \& Schleifer, K. H. (1983). Studies on the spectrometric determination of DNA hybridization from renaturation rates. Syst Appl Microbiol 4, 184-192.

Inagaki, F., Takai, K., Kobayashi, H., Nealson, K. H. \& Horikoshi, K. (2003). Sulfurimonas autotrophica gen. nov., sp. nov., a novel sulfur-oxidizing $\varepsilon$-proteobacterium isolated from hydrothermal sediments in the Mid-Okinawa Trough. Int J Syst Evol Microbiol 53, 1801-1805.

Inagaki, F., Takai, K., Nealson, K. H. \& Horikoshi, K. (2004). Sulfurovum lithotrophicum gen. nov., sp. nov., a novel sulfuroxidizing chemolithoautotroph within the $\varepsilon$-Proteobacteria isolated from Okinawa Trough hydrothermal sediments. Int J Syst Evol Microbiol 54, 1477-1482.

Lane, D. J. (1991). 16S/23S rRNA sequencing. In Nucleic Acid Techniques in Bacterial Systematics, pp. 115-175. Edited by E. Stackebrandt \& M. Goodfellow. Chichester: Wiley.

Lindeboom, H. J. (1984). The nitrogen pathway in a penguin rookery. Ecology 65, 269-277.

Llobet-Brossa, E., Rosselló-Mora, R. \& Amann, R. (1998). Microbial community composition of Wadden Sea sediments as revealed by fluorescence in situ hybridization. Appl Environ Microbiol 64, 2691-2696.

Maciolek, A. (1982). Lakes and lake-like waters of the Hawaiian Archipelago. Occ Pap Bernice P Bishop Mus 25, 1-14.

Mansfield, L. P. \& Forsythe, S. J. (2000). Arcobacter butzleri, A. skirrowii and A. cryaerophilus - potential emerging human pathogens. Rev Med Microbiol 11, 161-170.

Marmur, J. (1961). A procedure for the isolation of deoxyribonucleic acid from microorganisms. J Mol Biol 3, 208-218.

McClung, C. R., Patriquin, D. G. \& Davis, R. E. (1983). Campylobacter nitrofigilis sp. nov., a nitrogen-fixing bacterium associated with roots of Spartina alterniflora. Int J Syst Bacteriol 33, 605-612.

Miroshnichenko, M. L., Kostrikina, N. A., L'Haridon, S., Jeanthon, C., Hippe, H., Stackebrandt, E. \& Bonch-Osmolovskaya, E. A. (2002). Nautilia lithotrophica gen. nov., sp. nov., a thermophilic sulfurreducing $\varepsilon$-proteobacterium isolated from a deep-sea hydrothermal vent. Int J Syst Evol Microbiol 52, 1299-1304.

On, S. L. W. (1996). Identification methods for campylobacters, helicobacters, and related organisms. Clin Microbiol Rev 9, 405-422.

On, S. L. W. \& Holmes, B. (1991). Effect of inoculum size on the phenotypic characterization of Campylobacter species. J Clin Microbiol 29, 923-926.

On, S. L. W., Holmes, B. \& Sackin, M. J. (1996). A probability matrix for the identification of campylobacters, helicobacters, and allied taxa. J Appl Bacteriol 81, 425-432. 
Page, R. D. M. (1996). TreeView: an application to display phylogenetic trees on personal computers. Comput Appl Biosci 12, 357-358.

Perrière, G. \& Gouy, M. (1996). WWW-query: an on-line retrieval system for biological sequence banks. Biochimie 78, 364-369.

Pochon, J. \& Tardieux, P. (1962). Techniques d'Analyse en Microbiologie $d u$ Sol, p. 111. St Mandé, France: Editions de la Tourelle.

Saitou, N. \& Nei, M. (1987). The neighbor-joining method: a new method for reconstructing phylogenetic trees. Mol Biol Evol 4, 406-425.

Sasser, M. (1997). Identification of Bacteria by Gas Chromatography of Cellular Fatty Acids. MIDI Technical Note 101. Newark, DE: MIDI, Inc.

Savage, A. \& Knott, B. (1998). Artemia pathenogenetica in Lake Hayward, Western Australia. I. Interrupted recruitment into adult stages in response to seasonal limnology. Int J Salt Lake Res 7, $1-12$.

Schumacher, W., Kroneck, P. M. H. \& Pfennig, N. (1992). Comparative systematic study of "spirillum" 5175, Campylobacter and Wolinella species. Description of "spirillum" 5175 as Sulfurospirillum deleyianum gen. nov., sp. nov. Arch Microbiol 158, 287-293.

Sly, L. I., Blackall, L. L., Kraat, P. C., Tian-Shen, T. \& Sangkhobol, V. (1986). The use of second derivative plots for the determination of mol\% guanine plus cytosine of DNA by the thermal denaturation method. J Microbiol Methods 5, 139-156.

Takai, K., Nealson, K. H. \& Horikoshi, K. (2004). Hydrogenimonas thermophila gen. nov., sp. nov., a novel thermophilic, hydrogenoxidizing chemolithoautotroph within the $\varepsilon$-Proteobacteria, isolated from a black smoker in a Central Indian Ridge hydrothermal field. Int J Syst Evol Microbiol 54, 25-32.

Teske, A., Sigalevich, P., Cohen, Y. \& Muyzer, G. (1996). Molecular identification of bacteria from a coculture by denaturing gradient gel electrophoresis of $16 \mathrm{~S}$ ribosomal DNA fragments as a tool for isolation in pure cultures. Appl Environ Microbiol 62, 4210-4215.

Thompson, J. D., Gibson, T. J., Plewniak, F., Jeanmougin, F. \& Higgins, D. G. (1997). The CLUSTAL_X Windows interface: flexible strategies for multiple sequence alignment aided by quality analysis tools. Nucleic Acids Res 25, 4876-4882.

Vandamme, P., Falsen, E., Rossau, R., Hoste, B., Segers, P., Tytgat, R. \& De Ley, J. (1991). Revision of Campylobacter, Helicobacter and Wolinella taxonomy: emendation of generic descriptions and proposal of Arcobacter gen. nov. Int J Syst Bacteriol 41, 88-103.

Vandamme, P., Vancanneyt, M., Pot, B. \& 10 other authors (1992). Polyphasic taxonomic study of the emended genus Arcobacter with Arcobacter butzleri comb. nov. and Arcobacter skirrowii sp. nov., an aerotolerant bacterium isolated from veterinary specimens. Int J Syst Bacteriol 42, 344-356.

Wayne, L. G., Brenner, D. J., Colwell, R. R. \& 9 other authors (1987). International Committee on Systematic Bacteriology. Report of the ad hoc committee on reconciliation of approaches to bacterial systematics. Int J Syst Bacteriol 37, 463-464.

Wirsen, C. O., Sievert, S. M., Cavanaugh, C. M., Molyneaux, S. J., Ahmad, A., Taylor, L. T., DeLong, E. F. \& Taylor, C. D. (2002). Characterization of an autotrophic sulfide-oxidizing marine Arcobacter sp. that produces filamentous sulfur. Appl Environ Microbiol 68, 316-325. 